\title{
Constrains of the Multi-Sectoral Partnerships in Romania - Are Local Action Groups Sustainable?
}

\author{
Alexandru Olar ${ }^{*}$, Mugurel-Ionel Jitea \\ Department of Economic Sciences, University of Agricultural Sciences and Veterinary Medicine Cluj- \\ Napoca,3-5 Manastur Street, 400372 Cluj-Napoca, Romania
}

\begin{abstract}
Local Action Groups (LAGs) are responsible for promoting social and economic development in their territories, by creating local development strategies (LDSs) funded through LEADER Programme. They are area-based multisectoral partnerships, formed from public, private and social stakeholders. The aim of this paper is to study the governance and sustainability of Romanian LAGs, using evidence from the Nord-West Development Region from Romania. Structured interviews with LAGs managers were used as a primary method for collecting data. The results show that LAGs are struggling to remain active during the transition periods between two editions of the program, questioning their capacity to function without LEADER funding. However, they report fewer major changes compared to the last transition, mostly focusing on partnership and territorial structure.
\end{abstract}

Keywords: sustainability, transition, rural stakeholders, community-led local development.

\section{Introduction}

LEADER (Liaison Entre Actions de Développement de l'Économie Rurale) is a rural development method which has been used in the past 30 years as an alternative approach to the traditional top-down policies [1]. The method is based on seven core principles: the bottom-up approach, area-based approach, the local partnership, an integrated and multi-sectoral strategy, networking, cooperation and innovation, all of which having to be present and employed together [2]. The Local Action Groups (LAGs), as multi-actor partnerships created under LEADER, are responsible for implementing those features at local level [3]. However, due to their small budgets, LAGs are not able to have a big economic impact in their territories. For these reasons some authors are arguing that they are best suited to improve the living conditions in the

\footnotetext{
* Corresponding author: Alexandru Olar, Email: alexandru.olar@usamvcluj.ro

(cc) BY-NC-ND $@ 2021$ A. Olar et al., published by De Gruyter Open. This work was licensed under the Creative Commons Attribution-NonCommercialNoDerivs 3.0 License
}

rural areas by focusing more on innovative, social and non-productive projects [4]. Therefore, the local stakeholders should actively engage in identifying and prioritizing these innovative and unique development solutions that will form the basis of the Local Development Strategy (LDS) [5]. This requires a high level of understanding of LEADER methodology by local stakeholders, in the absence of which the effectiveness of the program can be questionable. However, they need time to gain enough experience in order to design and implement a strategy within the framework of LEADER [6]. Previous studies are pointing out some important problems that are limiting the performance of LAGs such as a lack of understanding of basic LEADER features, low involvement rates of partners and interferences from the local or national public administrations [68]. Such is also the case in Romania, where LDSs fail to respond to problems and opportunities related to knowledge transfer and the shift towards a climate resilient economy [9].

Giving the above mentioned challenges, it can be assumed that the correct implementation of the LEDER approach is strongly linked and 
determined by the LAGs governance mechanisms. Thus, the present study aims to: 1 ) determine the stakeholders' level of involvement in LAGs activities; 2) determine the level of sustainability of LAGs, especially during the transition periods between two editions of the program; 3) explore the relations between LAGs and management authorities. The results should help LAGs to better prepare for next CAP (Common Agricultural Policy) Programming Period.

\section{Material and Methods}

The research was conducted in the North West Development Region of Romania (corresponding to NUTS 2). During the 2007-2013 edition of LEADER there were 25 LAGs active in the region, while in the present programming period (20142020) the number of LAGs grew to 31, covering $80 \%$ of its territory.

Structured interviews with LAGs managers were used as a primary method for collecting data. The method is often used in LEADER related research $[10,11]$. The interview consisted in 12 questions divided in four sections (Table 1) and was designed after consultations with LAGs experts (researchers, LAG managers and consultants). Due to the SARS-CoV-2 virus pandemic constraints, the interviews were implemented by telephone between July and August 2020.

The questions were both open-ended and closedended. A Five Points Likert scale was used evaluate the respondents attitude regarding the involvement of the different categories of stakeholders in LAGs activities [12].

\section{Interview guide questions}

Table 1.

\section{Local Action Group characteristics}

Q1. Employees number; Open-ended;

Q2. Operating budget; Open-ended; In euro;

Q3. Partnership history; Open-ended;

Q4. Partnership structure; Open-Ended; Number of partners from each sector (public, private, NGO and relevant persons);

\section{Stakeholders involvement in LAG's activities}

Q5. Stakeholders involvement in the creation of the LDS (employees, consultants, private, public and NGOs and relevant persons); Open ended;

Q6. Stakeholders involvement in the LAG activities (employees, consultants, private, public and NGOs and relevant persons); Closed-Ended; Using a five-level Likert scale format, where 1 meant 'not at all' and excellent; For each of the following activities: animation, settlement of selection criteria, documents creation (guides, evaluation sheets, projects calls etc.), public representation;

\section{Sustainability}

Q7. Employees' status during the transition period between the two LEADER editions; Open ended;

Q8. Changes compared to the previous edition of the program; Open ended;

Q9. Employees' status during the next transition period (post 2020); Open-Ended;

Q10. Anticipated changes for the next LEADER edition (post 2020); Open-Ended;

Q11. Self-assessment of the LAGs sustainability without LEADER funding; Closed-Ended; Using a five-level Likert scale format, where 1 meant 'not at all' and 5"excellent';

\section{Cooperation with management authorities and funding agency;}

Q12. Cooperation with management authorities and funding agency; Open ended;

Source: Own data

In total, 21 responses were obtained. The method has some limitations. Firstly, it is based on the subjective opinion of LAG managers. Furthermore, it may introduce a bias, since the less successful LAGs are less likely to respond. Finally, the study was focused on only one development region and may not be generalized for the entire EU. Considering these limitations, the results can still be representative for the newer EU Members States, especially for Romania.

\section{Results and Discussion}

\section{LAGs characteristics}

On average, LAGs had a team consisting of 5.1 employees (Q1), and an operating budget of $463,429.00$ euro (Q2). The respondents argued that the small operating budget and the size of the team limits their capacity to respond to opportunities identified in the territory. Similar concerns were also raised by Ballesteros and Hernandez [13]. 
16 LAGs were active in the previous CAP Programming Period (2007-2013), while 5 were at their first experience implementing LEADER (Q3). In general, a partnership had a total of 58 members (Q4), with a few reaching over a hundred. About half of the partners (52\%) represent the private sector, followed by the public sector (25\%) and NGOs (23\%).

Stakeholders' involvement in LAGs activities 15 LAGs contracted external consultants to help writing the Local Development Strategies, while their team was involved in only 14 cases. A big concern is raised by the fact that in 6 cases (28\%) the consultants were the only ones involved in this process (Q5). This becomes even more worrisome when discussed in relation to partners' contribution. While in a few cases the respondents mentioned some important inputs of the partners (especially private ones), most of the time they were only formally consulted, contrary to the participative bottom-up approach promoted by LEADER [13]. In this context Respondent no. 4 stated that "LAGs should act as a forum for the partners to discuss and promote their ideas and solutions for the development of the rural area, and then transform this local knowledge into financial instruments in their strategic plans."

Following the creation of the strategies, 13 LAGs continued to rely on the services of private consultants. Their most important attributions were to assist in creation of documents such as the project calls, applicant guides, and evaluation sheets (an average of 3.31 points on Likert scale), and were less involved in the other activities.

As expected, LAG employees scored high (above 4.6) at every measured activity. They had the best results in the above mentioned category (4.95), while the other stakeholders were less involved (1.67 for each type). The private partners were more involved in the settling of the selection criteria (3.10), while the public stakeholders in the animation (3.57) and public representation of LAGs (3.29). All three sectors equally participated in good-practice models exchange and other networking related activities (3.33) (Q6).Thus, the results suggest that the public stakeholders are more interested in the public events, helping LAGs to organize meetings, while the private partners prefer to mainly influence the strategic decisions. Contrary to the expectations, the NGO partners had low levels of involvement in almost every activity, suggesting that they do not see LAG membership as an opportunity to enhance their own activity. The results confirm in part the concerns raised in the introduction section, regarding the partners' low level of involvement [8].

\section{Sustainability}

The results show that most LAGs had difficulties maintaining their employees during the transition period between the two LEADER editions (20072013 and 2014-2020). Only ten LAGs managed to remain active during this time: six at full capacity and 4 with a reduced team (Q7). This questions the LAGs capacity to function without LEADER funding. However, some positive changes can be seen regarding the next transition period. Most LAGs plan to continue the activity at full capacity and with a full team (11), while four LAGs will reduce either the team size (2) or will opt for the part-time system (2). On the other hand four LAGs are unsure and still looking for a solution, while two of the respondents admitted that their organizations cannot support any employee, and will have to suspend their activity (Q9). Regarding this matter, Respondent no. 21 argued: "Our efforts are focused on maintaining the team. It is difficult to start again with new employees, because they will have not only to learn the method, but also to familiarize themselves with the territory and members of the partnership." These concerns are in line with those raised by Volk and Bojnec [6], who highlighted the time that partnerships need in order to learn the method and become operational.

The respondents were asked to discuss the most important changes that were made in preparation of the 2014-2020 CAP Programming Period (Q8), and the ones planned for the following period (Q10) (Table 2).

Important changes made and anticipated by LAGs

\begin{tabular}{l|lllll}
\hline \multicolumn{6}{c}{ Important changes made and anticipated by LAGs } \\
\hline Programming Period & Team & Management & Territory & $\begin{array}{l}\text { Partnership } \\
\text { Structure }\end{array}$ & $\begin{array}{l}\text { No Major } \\
\text { Changes }\end{array}$ \\
\hline 2007-2013 (Q8)-16 LAGs & $10(62.5 \%)$ & $5(31.25 \%)$ & $11(68.75 \%)$ & $13(81.25 \%)$ & $2(12.5 \%)$ \\
\hline 2014-2020 (Q10)-21 LAGs & $6(28.57 \%)$ & $0(0 \%)$ & $7(33.33 \%)$ & $7(33.33 \%)$ & $7(33.33 \%)$
\end{tabular}

Source: own results; Based on the frequency of the responses; 
In total 14 LAGs (87.5\%) reported such changes in the first transition period. Most of them were related to the territory (69\%) and partnership structure (81\%). In general, LAGs tried to extend their territory (8 cases) with municipalities that were not previously covered by LEADER. By doing so, they managed to attract more funds, since the budget allocations from LEADER are directly linked to the LAGs population and territory size.

Other important changes reported by LAGs were related to management and their team. The last ones were a direct consequence of the LAGs inability to continue their activity during the transition period. Although a few of them managed to re-hire some of their former employees, most of them failed to do so. This loss of experience can represent a serious problem when dealing with a complex methodology such as LEADER [6]. Moreover, two LAGs were also forced to reduce the size of their teams due to the small operating budgets (Q8).

For the next transition period only 14 respondents (66.66\%) foresaw the need to implement some major changes. In contrast to the previous period, more LAGs have identified methods to remain active until the next edition of the Programme, which allows them to maintain their team. Fewer changes were also reported regarding the partnership and territorial structure. However, the next transition period comes with new and unexpected challenges. The SARS-CoV-2 pandemic and the withdrawal of the United Kingdom (UK) from the European Union are likely to cause significant delays between the CAP Programming Periods. The respondents admitted that the LAGs are not ready to face a longer transition period, and they will need additional budget allocations (Q10). Talking about this subject, Respondent no. 5 stated: "We really hope that the transition will be a short one. Otherwise we'll have to start from scratch again."

An alarming situation was reported for both periods. Respondents admitted that in some cases territorial and partnership changes have a political basis and are a direct consequence of the local election results. This suggests that, contrary to the bottom-up approach principle, the public actors maintain a high level of influence inside the partnership, using LAGs as instruments of power, as shown in other studies [14]. Fortunately not all such changes are politically motivated, as some LAGs are aiming to replace the partners with a low level of involvement and even to increase proportion of private and NGO stakeholders.

With an average score of 2.05, most of the respondents consider that LAGs cannot continue their activity without LEADER funding (Q11). Only two respondents considered that it is possible, but "it is very difficult and unlikely for many groups" (Respondent 9). Respondent no. 3 stated that "in order to be sustainable LAGs have to identify and use other financial instruments along those provided by LEADER".

Cooperation with management authorities and funding agency;

Although most LAGs consider that, in general, the relations with the management authorities and funding agencies were good, the respondents pointed out that there were some important shortcomings. Half of the respondents agreed that these institutions are reluctant when considering some of the more innovative measures and projects. Therefore, LAGs are discouraged to create and propose such initiatives, and become inclined to choose the more generic approach. However, this is contrary to LEADER initial objective, to be a "Laboratory for innovative solutions". Alonso and Masot [4] are also arguing that LAG measures are best suited to support innovative and social projects, since the budget allocations are too small to have a big impact on the more traditional aspects such as job creation. The respondents also reported in some cases a lack of understanding (especially at county level) of LEADER specific procedures (6 responses), and poor communication skills (3 responses). Respondent no. 21 pointed out that "because LAGs work with different procedures, the management authorities perceives us as some kind of extra work", while respondent no. 6 argued that this often results in significant delays.

\section{Conclusions}

The results show that, despite some progress since the last LEADER edition, Romanian LAGs are still likely to face difficulties during the next transition period. The partnerships are slow in finding alternative financial solutions outside the LEADER specific ones, resulting in a low level of sustainability. Moreover, the frequent changes in partnership and team structures reduce their capacity to apply the complex methodology, producing important delays in implementation of LDS. LAGs also face a relative low level of involvement from the non-public stakeholders, contrary to the principles of community-led local development. The results should help underline the challenges that LAGs are confronting and allow them to prepare for the next transition and implementation periods. Giving the scope and limitations of the present study, further research should focus on the stakeholders directly, to better study their involvement and role in LAGs. 


\section{References}

1. Dax, T., \& Oedl-Wieser, T. (2016). Rural innovation activities as a means for changing development perspectives An assessment of more than two decades of promoting LEADER initiatives across the European Union. Studies in Agricultural Economics. 118. 30-37. 10.7896/j.1535;

2. Bumbalová, M., Takáč, I., Tvrdoňová, J., \& Valach, M. (2016). "Are Stakeholders in Slovakia Ready for Community-Led Local Development? Case Study Findings" European Countryside, vol.8, no.2, pp.160174., 10.1515/euco-2016-0013;

3. Masot N. A. \& Cárdenas Alonso G. (2017). 25 Years of the Leader Initiative as European Rural Development Policy: The Case of Extremadura (SW Spain), European Countryside, 9(2), 302-316. 10.1515/euco-2017-0019

4. Cárdenas Alonso G. \& Masot N. (2020). A. Rural space governance in Extremadura (SW Spain). Analysis of the Leader Approach. European Countryside, 12. 448-468. 10.2478/euco-2020-0024;

5. Yagiue, J.L., de Nicolas, V.L. \& Martinez, J.L. (2013). Leader Rural Development Program in Spain: Profile and Functions of Workers in Local Action Groups.. In: "The Sixth International Scientific Conference Rural Development 2013. Innovations and Sustainaibility", Akademija. Lithuania;

6. Volk, A. \& Bojnec, S. (2014). Local action groups and the LEADER co-financing of rural development projects in Slovenia. Agricultural Economics (Czech Republic). $\quad 60 . \quad 364-375 . \quad 10.17221 / 180 / 2013-$ AGRICECON.

7. Arroyo, F.M., López, H.S. \& Blanco, José. (2015). Are local action groups, under LEADER approach, a good way to support resilience in rural areas?. Ager. 39-63. 10.4422/ager.2015.06

8. Zajda, K. (2014). Problems of functioning of Polish local action groups from the perspective of the social capital concept. Eastern European Countryside. 20. 10.2478/eec-2014-0004.

9. Olar A. \& Jitea I.M. (2020). Assessing the quality of the local development strategies in Romania, evidence from 2014-2020 programming period. Scientific Papers Series Management, Economic Engineering in Agriculture and Rural Development, 20(2): 347 - 358;

10. Pérez-Fra, M., Lopez I.E., Arias, A.I., Sineiro G. F. \& Lorenzana, R. (2012). Representativeness and civic participation in rural development programmes The case of the PRODER programme in Galicia, Spain. Outlook on agriculture. 410098. 215-220. 10.5367/oa.2012.0098.

11. Navarro, F., Cejudo, E. \& Maroto, J. (2016). Participation of disadvantaged groups and governance in the LEADER and PRODER programmes in Andalucía, Spain. Studies in Agricultural Economics. 118. 47-54. 10.7896/j.1532.

12. Joshi A., Saket K., Satish C. \& Dinesh P. (2015) Likert Scale: Explored and Explained. British Journal of Applied Science \& Technology, 7. 396-403. 10.9734/BJAST/2015/14975;

13. Ballesteros J. G. T. \& Hernández M. H. (2018). Promoting tourism through the EU LEADER programme: understanding Local Action Group governance, European Planning Studies, 27, 396-414, 10.1080/09654313.2018.1547368;

14. Esparcia, J., Escribano, J. \& Serrano, J. (2015). From development to power relations and territorial governance: Increasing the leadership role of LEADER Local Action Groups in Spain. Journal of Rural Studies. $42 . \quad 29-42 . \quad 10.1016 / j$.jrurstud.2015.09.005. 